\title{
HVMANITAS
}

[Recensão a] Rodrígez Alfageme, Ignacio - Aristófanes: escena y comedia

Autor(es): $\quad$ Silva, Maria de Fátima

Publicado por: Faculdade de Letras da Universidade de Coimbra, Instituto de Estudos

URL

persistente: URI:http://hdl.handle.net/10316.2/27971

DOI: $\quad$ DOI:http://dx.doi.org/10.14195/2183-1718_61_25

Accessed : $\quad$ 26-Apr-2023 11:38:41

A navegação consulta e descarregamento dos títulos inseridos nas Bibliotecas Digitais UC Digitalis, UC Pombalina e UC Impactum, pressupõem a aceitação plena e sem reservas dos Termos e Condições de Uso destas Bibliotecas Digitais, disponíveis em https://digitalis.uc.pt/pt-pt/termos.

Conforme exposto nos referidos Termos e Condições de Uso, o descarregamento de títulos de acesso restrito requer uma licença válida de autorização devendo o utilizador aceder ao(s) documento(s) a partir de um endereço de IP da instituição detentora da supramencionada licença.

Ao utilizador é apenas permitido o descarregamento para uso pessoal, pelo que o emprego do(s) título(s) descarregado(s) para outro fim, designadamente comercial, carece de autorização do respetivo autor ou editor da obra.

Na medida em que todas as obras da UC Digitalis se encontram protegidas pelo Código do Direito de Autor e Direitos Conexos e demais legislação aplicável, toda a cópia, parcial ou total, deste documento, nos casos em que é legalmente admitida, deverá conter ou fazer-se acompanhar por este aviso. 
humanitas

\section{Vol. LXI}

IMPRENSA DA UNIVERSIDADE DE COIMBRA

COIMBRA UNIVERSITY PRESS 


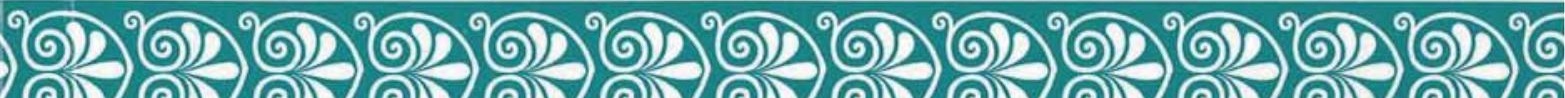

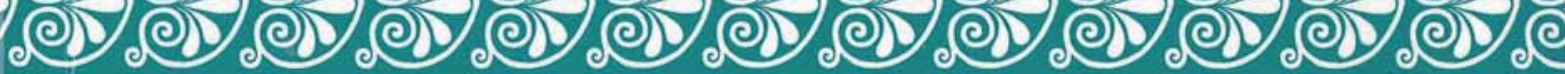

Vol. LXI 
ter incluído outra de Lisboa (CIL II 194), bastante significativa. Muito merecedora de atenção é a imitatio Alexandri (pp. 243-253) e o falhanço da política oriental de Roma, custosa sob todos os aspectos. A renúncia à Germânia, após o desastre de Teutoburgo, há dois mil anos, foi mais importante para o Ocidente do que as obstinadas tentativas orientais de um Império que, transformando-se e afastando-se gradualmente da concepção própria da cidade antiga, perdeu a energia e a vontade de fazer história ${ }^{22}$. Por aquilo com que concordo e por aquilo com que discordo, considero muito pertinente a leitura desta obra de Alejandro Bancalari Molina.

\section{Vasco Gil Mantas (Universidade de Coimbra)}

Rodrígez Alfageme, Ignacio, Aristófanes: escena y comedia, Madrid, Editorial Complutense, 2008, 421 pp. ISBN: 9788474919325

Os estudos sobre Comédia Grega Antiga e sobre aquele que constitui o seu principal testemunho, Aristófanes, passam a dispor de um título recente, de clara valia para os que se interessam pelo assunto. Refiro-me não só aos estudiosos de teatro grego provenientes dos Estudos Clássicos, mas também àqueles que se situam no âmbito dos Estudos Teatrais ou na execução prática da representação. De há muito conhecido pelos seus estudos sobre teatro grego, sobretudo cómico, Alfageme sistematiza e aprofunda, neste seu livro, resultados obtidos durante anos de investigação e de troca de opiniões com outros especialistas. De facto, uma das qualidades que importa sublinhar é a amplitude da bibliografia consultada, que permite uma visão diacrónica do progresso feito neste campo, como a identificação das questões mais polémicas que têm, a partir do séc. XIX, dividido opiniões. Deste percurso é imagem a longa e bem documentada bibliografia geral que encerra o volume. Por isso, este estudo aparece, antes de mais, como uma sistematização crítica e actualizada da erudição sobre Comédia Antiga e Aristófanes.

Uma simples consulta do índice é reveladora da hierarquia das opções tomadas pelo Autor. Ao longo de sete dezenas de páginas introdutórias, as questões ligadas ao género cómico e à produção de Aristófanes repartem-

${ }^{22}$ Todos os povos têm História, passiva para uns, activa para outros (die Geschichten machen), de acordo com o conceito alemão. 
se em duas perspectivas essenciais: aspectos cénicos e elementos literários. A própria ordenação das matérias não deixa dúvidas sobre a prioridade assumida: a de valorizar os problemas cénicos sobre a tradicional vantagem dada ao texto.

$\mathrm{Na}$ sua abordagem, Alfageme começa por regressar à discussão de conceitos dramáticos, o de opsis por exemplo, num propósito de se abrir a uma diacronia mais ampla, que se vale do recurso frequente à teoria aristotélica, sem perder de vista passos importantes dados pelos modernos teorizadores teatrais, no que se refere à concepção do espectáculo. Sem prejuízo de considerações de natureza mais teórica, este estudo global envereda por uma análise detalhada dos recursos de cena, como dança / coro, movimento / actores, ritmo da acção, caracterização, em termos de vestuário e máscaras, dos intervenientes. Aspectos particularmente controversos, como o possível envolvimento directo do poeta na representação, o número de portas disponíveis no cenário, a gestão do tempo e do espaço na comédia, são tratadas com minúcia, a partir de um confronto de depoimentos alargados. Além do recurso ao testemunho arqueológico, técnico e cultural, tratados com particular rigor no que se refere à flutuação diacrónica, o que o Autor chama 'cenografia verbal' ou seja, a informação incorporada no texto, abre um amplo espectro de testemunhos, na busca da resposta autorizada a um eterno desafio: a que linhas e preferências obedecia a representação daquelas peças que continuam a ser, para nós, hoje em dia sobretudo 'textos'? É de louvar a sobriedade que Alfageme coloca na avaliação dos recursos materiais que caracterizam o cenário e a forma sensível como sublinha a tendência para a abstracção, auxiliada por uma conivência ou convenção entre poeta e audiência. É aliás interessante a presença que o público, o grande ausente na consideração moderna da dinâmica teatral antiga, tem neste estudo, de acordo com a noção clara da sua interferência nos objectivos e execução do espectáculo. Uma alusão rápida se impõe ao conjunto de imagens, fotografias de materiais ilustrativos ou de esquemas, que apoiam, com utilidade, a teorização desenvolvida.

A partir da p. 60, o estudo introdutório volta-se para a forma literária das comédias. Partindo da sensação de falta de coesão que parece própria da índole do género, Alfageme regressa à definição das partes tradicionais do esquema dramático, fazendo uma aproximação útil entre tragédia e comédia. Cada uma das suas componentes elementares - prólogo, agôn, parábase, cenas iâmbicas e êxodo - é avaliada na sua configuração dramática e formal, e definidas as suas funções e estratégias específicas. Às 
etapas sucessivas do esquema, o estudioso soma a discussão da ideia mais global de 'duas partes' (pp. 61-62, 69), pré e pós parábase, que permitem uma outra visão mais alargada da dinâmica de fundo que preside ao conjunto, na reavaliação de sugestões que ascendem aos primeiros anos do séc. XX.

Somando os dois planos por que desenvolve a sua introdução, o Autor aborda, em correlação, o que chama unidade de acção cénica - cada cena - e unidade de acção dramática ou textual, que se combinam no que pode chamar-se 'situação'. A análise da execução em causa nestas duas unidades constitui uma forma estimulante - e quiçá até menos explorada - de promover o nexo entre os dois planos de cada peça, a concepção literária e a transposição cénica.

Após o estudo introdutório, o Autor executa uma averiguação peça a peça, de acordo com os critérios antes definidos sobre o que seja 'cena' ou 'sequência de cenas'. Trata-se, portanto, de uma metodologia que assenta na construção ou estrutura dramática e sua repercussão cénica. São materiais valorizados as rubricas de cena, colhidas do próprio texto, que abonam a movimentação executada; o número de versos envolvido em cada unidade, que produza um efeito geral de uma certa proporção; fórmulas que estabeleçam a marcação clara do início e fecho de cada unidade cénica. A inclusão de esquemas permite visualizar, de modo sistemático, o resultado de uma análise minuciosa e eminentemente técnica.

Um capítulo final de conclusões entrelaça os elementos usados de modo a valorizar, como Alfageme sublinha (p. 365), 'as complexas relações que se estabelecem entre as cenas (a parte espectacular da obra de teatro) com a acção dramática', como também 'uma série de estratégias comuns', que se repetem em diferentes peças.

Em conclusão, este é um livro que espelha uma reflexão amadurecida das questões suscitadas sobre a Comédia Grega Antiga e que sobretudo faz o percurso diacrónico das teorias emitidas, sobre que exerce uma avaliação crítica. A este, que considero um dos seus méritos principais, junta-se o de harmonizar as duas faces do fenómeno, a literária e a cénica, que tendem, com frequência, a manter-se divorciadas e motivadoras de estudos em separado. Quando, obviamente, são indissociáveis e mutuamente condicionadoras.

Maria de Fátima Silva (Universidade de Coimbra) 